\title{
Study on sensitivity of national annual pollutant emission from passenger cars to traffic patterns
}

The paper presents the results of the study on the sensitivity of the national annual pollutant emission from passenger cars to traffic patterns. The study was carried out in accordance with the methodology applied in the COPERT 4 software. The traffic pattern was modelled as the share of road lengths under various traffic conditions: urban, rural and on motorways and expressways, in the total length of trips covered by vehicles. A relatively small and less varied sensitivity of the national annual pollutant emission from passenger cars to the traffic pattern was found due to the substance emitted. This was considered to be a valuable proposal for the selection of parameters for the total emission model of vehicular pollutants, in view of the difficulty of estimating the share of road lengths under model traffic conditions.

Key words: motor vehicles, inventory of pollutant emission, COPERT

\section{Introduction}

The performance parameters of internal combustion engines are highly sensitive to the operating conditions of the engines $[7,8]$. Particularly sensitive to engine operating conditions is the emission of pollutants $[1,7,8]$.

The sensitivity of operational properties of internal combustion engines to their operation conditions is related not only to values describing these conditions but also to the occurrence of dynamic states [7, 8]. Particularly in the dynamic states whose diversity is endless, the engine performance parameters may vary considerably from that of static states [7, 8].

The operating conditions of internal combustion engines can be described in terms of the engine thermal state and its work intensity $[7,8]$. Under thermally stabilized conditions, the engine performance is usually described by torque output and engine crankshaft speed [7, 8]. Under traction use of an internal combustion engine, the latter values are determined primarily by the vehicle velocity [7].

The engine operating conditions may vary substantially between various models of road traffic. At the same time, the road traffic modelling encounters difficulties in identifying model parameters, thus, it is purposeful to investigate the sensitivity of the performance properties of internal combustion engines to these parameters.

The parameters of operating conditions of the internal combustion engine, determined by the process of vehicle velocity, include [1-6, 9-14]:

- share of vehicle mileage under model traffic conditions,

- average velocity of vehicles under model traffic conditions.

The following model traffic conditions have been assumed in the studies on the total emission from motor vehicles [1-6, 9-14]:

- urban,

- rural,

- on highways and expressways.

Particularly significant differences in the engine operating conditions occur in the case of passenger cars [1, 7]. For this reason, a study was undertaken to assess the sensitivity of the national annual pollutant emission from passenger cars to the traffic patterns. In this paper, we focused on the mileage of cars under model traffic conditions.

\section{COPERT 4 software applied in this work}

The COPERT 4 software [10-12,14] was used for the simulation study. This is the preferred software in the European Union, for the inventory of pollutants from motor vehicles [14].

The study was conducted for the state of the automotive industry in Poland in 2015.The values entered as software data are given in table 1 .

\section{Table 1. Values characterising the traffic of passenger cars in Poland in 2015}

\begin{tabular}{|r|r|r|}
\hline $\mathrm{N}_{\text {PC }}$ & {$[\mathrm{mln}]$} & 20.52 \\
\hline $\mathrm{N}_{\text {PC-SI }}$ & & 14.66 \\
\hline $\mathrm{N}_{\text {PC-CI }}$ & & 5.86 \\
\hline $\mathrm{p}_{\text {PC-SI }}$ & {$[\mathrm{km}]$} & 5900 \\
\hline $\mathrm{p}_{\mathrm{PC}-\mathrm{CI}}$ & {$[\mathrm{km}]$} & 12300 \\
\hline $\mathrm{u}_{\mathrm{U}}$ & & 0.37 \\
\hline $\mathrm{u}_{\mathrm{R}}$ & & 0.5 \\
\hline $\mathrm{u}_{\mathrm{H}}$ & & 0.13 \\
\hline $\mathrm{v}_{\mathrm{U}}$ & {$[\mathrm{km} / \mathrm{h}]$} & 31.5 \\
\hline $\mathrm{v}_{\mathrm{R}}$ & {$[\mathrm{km} / \mathrm{h}]$} & 70 \\
\hline $\mathrm{v}_{\mathrm{H}}$ & {$[\mathrm{km} / \mathrm{h}]$} & 120 \\
\hline
\end{tabular}

The number of passenger cars was estimated based on data of the Central Statistical Office of 2015. The number of passenger cars applies to all vehicles $-\mathrm{N}_{\mathrm{PC}}$ and to cars with spark ignition engine $-\mathrm{N}_{\mathrm{PC}-\mathrm{SI}}$ as well as to those with compression ignition engine $-\mathrm{N}_{\mathrm{PC}-\mathrm{SI}}$.

The annual mileage of passenger cars with spark ignition engine $-\mathrm{p}_{\mathrm{PC}-\mathrm{SI}}$ as well as of those with compression

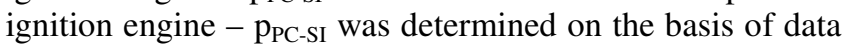
contained in [6].

The model simulating vehicle use intensity, developed specifically by the authors and built on the basis of functional likeness, was applied to elementary categories of cars relating to pollutant emission.

Data on vehicle structure at the level of elementary category were used to identify the model ([13]). The 
definition of traffic patterns [4, 9] was assumed in accordance with data contained in [6].

The average distance travelled by the vehicle after start-up, which is used to determine the pollutant emission attributable to engine warming, was assumed to be $12 \mathrm{~km}$ [2].

The remaining parameters of the COPERT 4 model were assumed in accordance with the parameters suggested by the software equipment. Those parameters refer to, among others, fuel characteristics as well as to climatic data for a particular country.

\section{Results of simulation study}

Two types of simulation studies were performed (Table 2).

In the first study, the share of traffic on highways and motorways $-\mathrm{u}_{\mathrm{H}}$ in the model traffic conditions, was assumed to be constant, while the shares of urban traffic $\mathrm{u}_{\mathrm{U}}$ and rural traffic $-\mathrm{u}_{\mathrm{R}}$ were used as variables.

Table 2. Schematic of studies Nos 1 and 2

\begin{tabular}{|c|c|c|c|c|c|}
\hline \multicolumn{3}{|c|}{ Study No 1 } & \multicolumn{3}{c|}{ Study No 2 } \\
\hline $\mathrm{u}_{\mathrm{U}}$ & $\mathrm{u}_{\mathrm{R}}$ & $\mathrm{u}_{\mathrm{H}}$ & $\mathrm{u}_{\mathrm{U}}$ & $\mathrm{u}_{\mathrm{R}}$ & $\mathrm{u}_{\mathrm{H}}$ \\
\hline 0.29 & 0.58 & 0.13 & 0.39 & 0.58 & 0.03 \\
\hline 0.34 & 0.53 & 0.13 & 0.39 & 0.53 & 0.08 \\
\hline 0.39 & 0.48 & 0.13 & 0.39 & 0.48 & 0.13 \\
\hline 0.44 & 0.43 & 0.13 & 0.39 & 0.43 & 0.18 \\
\hline 0.49 & 0.38 & 0.13 & 0.39 & 0.38 & 0.23 \\
\hline
\end{tabular}

In Figures 1-7, the results are presented of the simulation study No 1: the dependence of the annual national emission of selected pollutants from passenger cars upon the share of road length under the following model traffic conditions: $\mathrm{U}$ - in towns, $\mathrm{R}$ - outside towns, $\mathrm{H}$ - on highways and expressways and $\mathrm{T}-$ under all conditions.

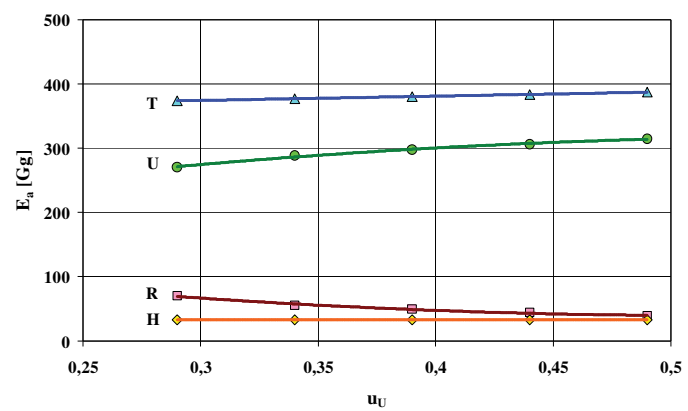

Fig. 1. Dependence of the national annual emission of carbon monoxide from passenger cars upon the road length travelled under the following model traffic conditions: $\mathrm{U}$ - urban, $\mathrm{R}$ - rural, $\mathrm{H}$ - on highways and expressways and $\mathrm{T}-$ under all conditions

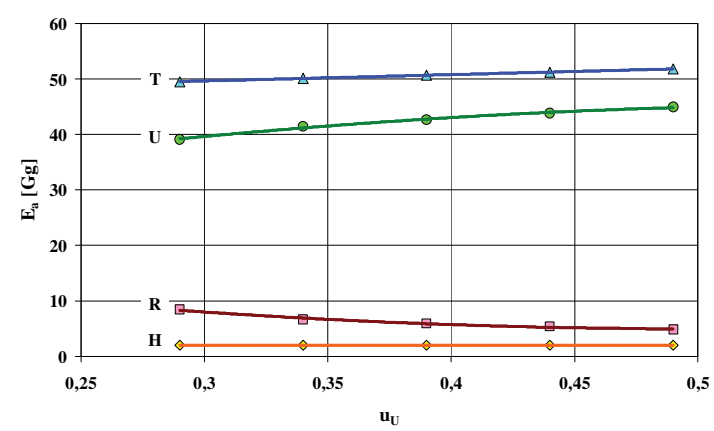

Fig. 2. Dependence of the national annual emission of volatile organic compounds from passenger cars upon the road length travelled under the following model traffic conditions: $\mathrm{U}$ - urban, $\mathrm{R}$ - rural, $\mathrm{H}$ - on highways and expressways and $\mathrm{T}-$ under all conditions

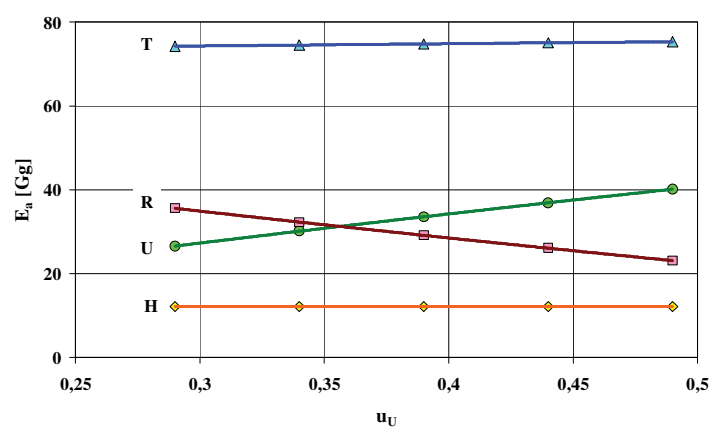

Fig. 3. Dependence of the national annual emission of nitrogen oxides from passenger cars upon the road length travelled under the following model traffic conditions: $\mathrm{U}$ - urban, $\mathrm{R}$ - rural, $\mathrm{H}$ - on highways and expressways and $\mathrm{T}-$ under all conditions

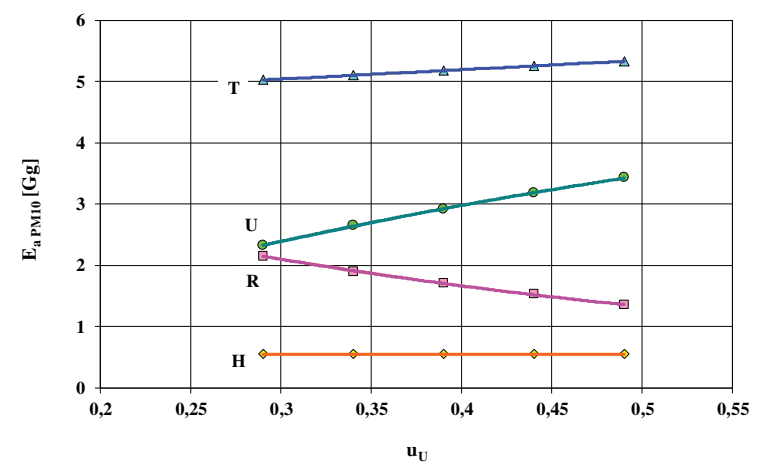

Fig. 4. Dependence of the national annual emission of particulate matter PM10 from tribological elements of passenger cars upon the road length travelled under the following model traffic conditions: $\mathrm{U}$ - urban, R rural, $\mathrm{H}$ - on highways and expressways and $\mathrm{T}-$ under all conditions

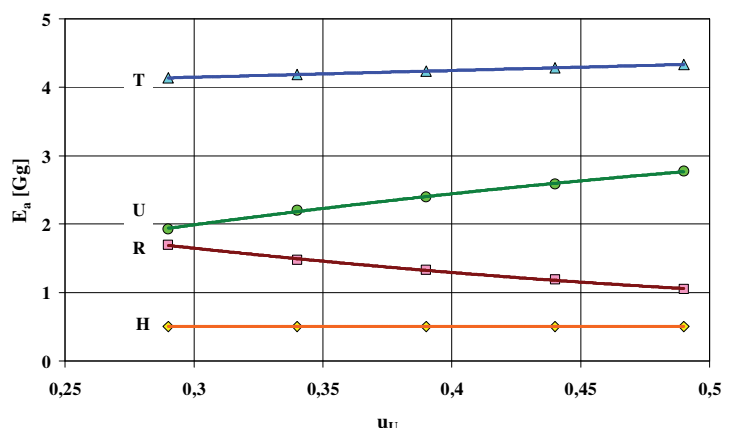

Fig. 5. Dependence of the national annual emission of particulate matter PM2.5 from tribological elements of passenger cars upon the road length travelled under the following model traffic conditions: $\mathrm{U}$ - urban, R rural, $\mathrm{H}$ - on highways and expressways and $\mathrm{T}-$ under all conditions

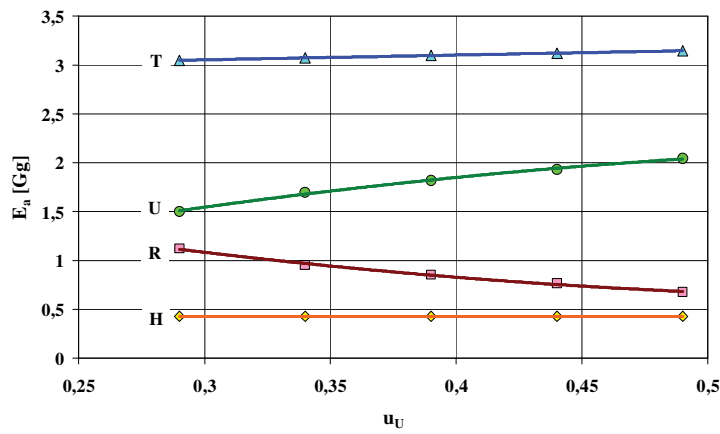

Fig. 6. Dependence of the national annual emission of particulate matter from the exhaust system of passenger cars engines upon the road length travelled under the following model traffic conditions: $\mathrm{U}-$ urban, $\mathrm{R}-$ rural, $\mathrm{H}$ - on highways and expressways and $\mathrm{T}-$ under all conditions 


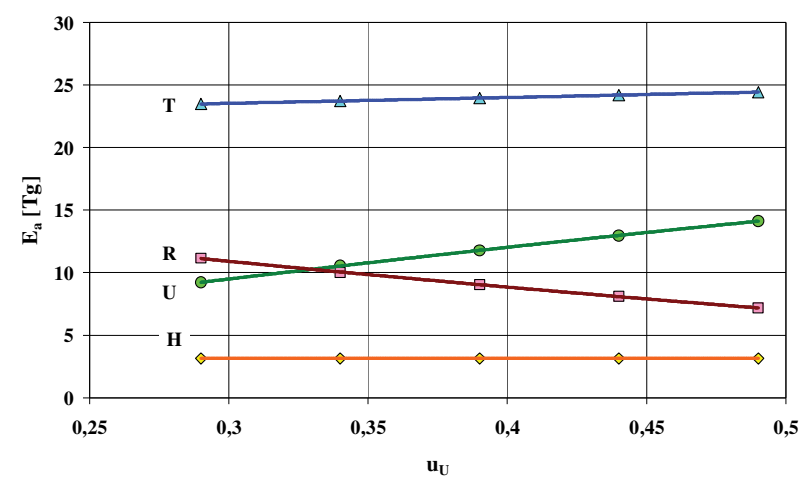

Fig. 7. Dependence of the national annual emission of carbon dioxide from passenger cars upon the road length travelled under the following model traffic conditions: $\mathrm{U}$ - urban, $\mathrm{R}$ - rural, $\mathrm{H}$ - on highways and expressways and $\mathrm{T}$ - under all conditions

In Figures $8-15$, the results are presented of the simulation study No 2: the dependence of the national annual emission of selected pollutants upon the share of road length under the following model traffic conditions: $\mathrm{U}$ - urban, $\mathrm{R}$ - rural, $\mathrm{H}$ - on highways and expressways and $\mathrm{T}$ - under all conditions.

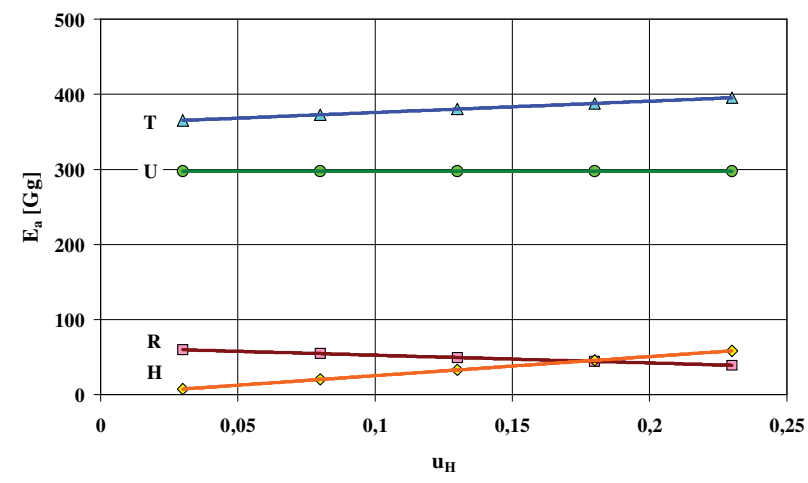

Fig. 8. Dependence of the national annual emission of carbon monoxide from passenger cars upon the road length travelled under the following model traffic conditions: $\mathrm{U}$ - urban, $\mathrm{R}$ - rural, $\mathrm{H}$ - on highways and expressways as well as $\mathrm{T}-$ under all conditions

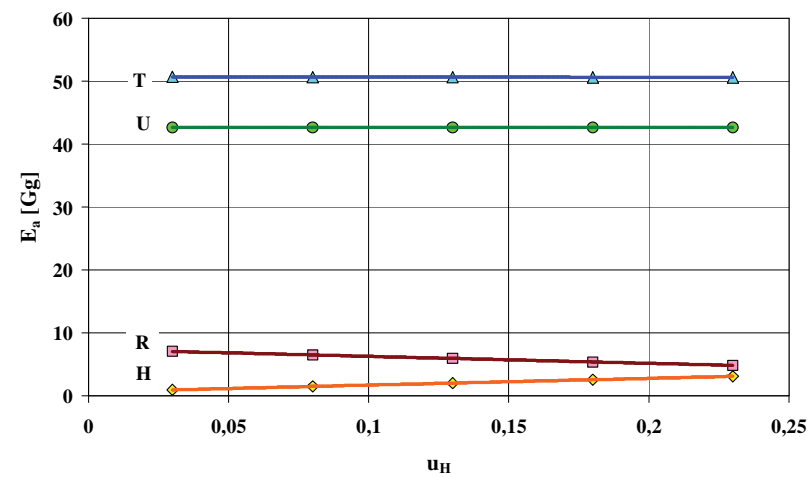

Fig. 9. Dependence of the national annual emission of volatile organic compounds from passenger cars upon the road length travelled under the following model traffic conditions: $\mathrm{U}$ - urban, $\mathrm{R}$ - rural, $\mathrm{H}$ - on highways and expressways as well as $\mathrm{T}-$ under all conditions

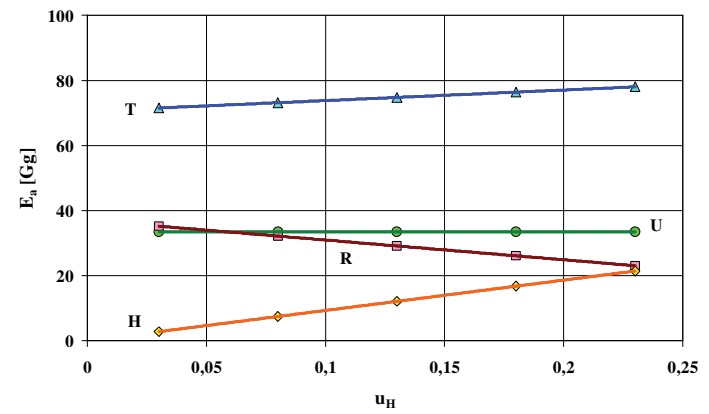

Fig. 10. Dependence of the national annual emission of nitrogen oxides from passenger cars upon the road length travelled under the following model traffic conditions: $\mathrm{U}$ - urban, $\mathrm{R}$ - rural, $\mathrm{H}$ - on highways and expressways as well as $\mathrm{T}-$ under all conditions

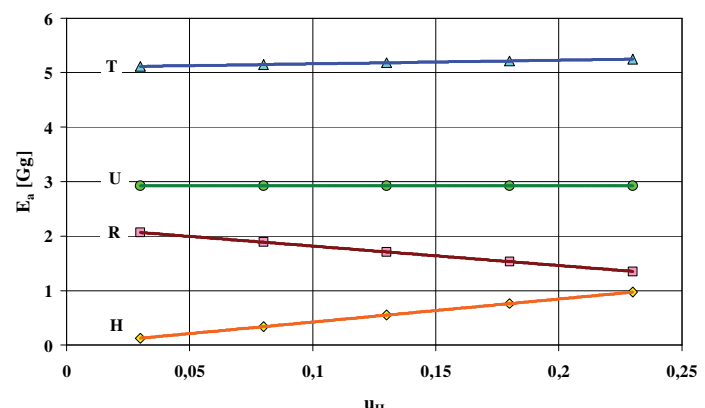

Fig. 11. Dependence of the national annual emission of particulate matter PM10 from tribological elements of passenger cars upon the road length travelled under the following model traffic conditions: $\mathrm{U}$ - urban, R- rural,

$\mathrm{H}-$ on highways and expressways as well as $\mathrm{T}-$ under all conditions

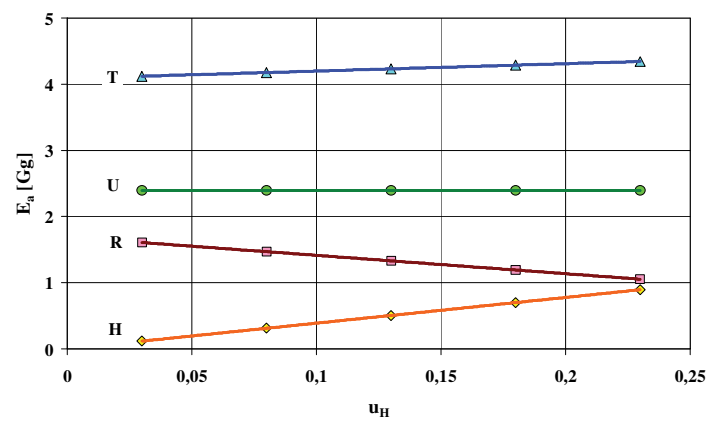

Fig. 12. Dependence of the national annual emission of particulate matter PM2.5 from tribological elements of passenger cars upon the road length travelled under the following model traffic conditions: $\mathrm{U}-$ urban, $\mathrm{R}-$ rural, $\mathrm{H}-$ on highways and expressways as well as $\mathrm{T}-$ under all conditions

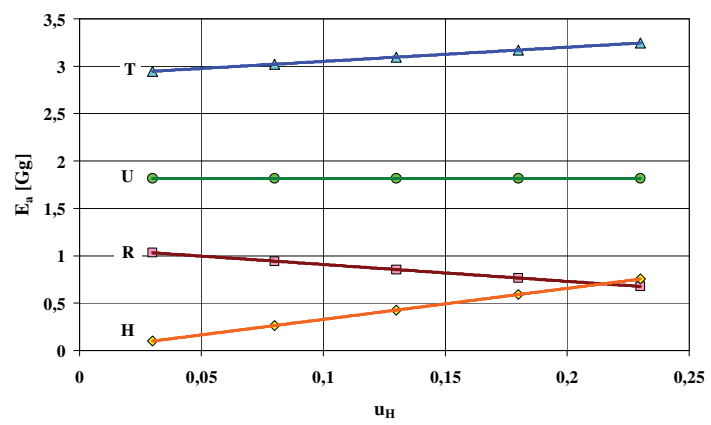

Fig. 13. Dependence of the national annual emission of particulate matter from the exhaust system of passenger cars engines cars upon the road length travelled under the following model traffic conditions: $\mathrm{U}-$ urban, $\mathrm{R}$ - rural, $\mathrm{H}$ - on highways and expressways as well as $\mathrm{T}$ - under all conditions 


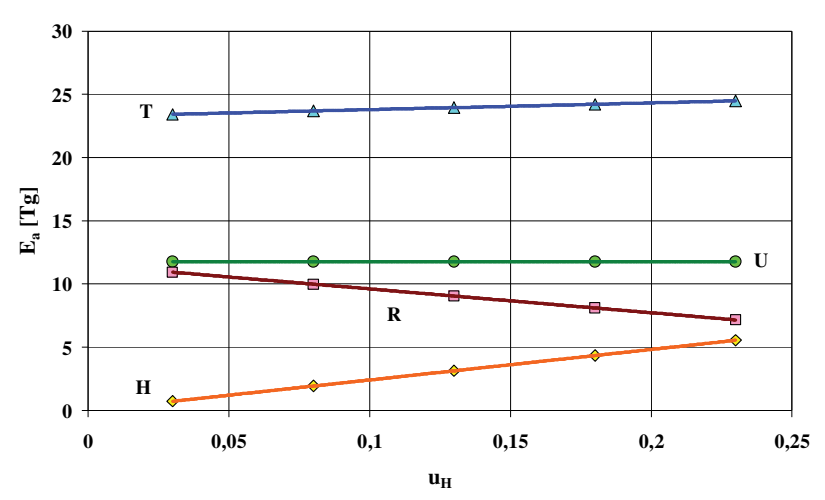

Fig. 14. Dependence of the national annual emission of carbon dioxide from passenger cars upon the share of road length travelled under the following model traffic conditions: $\mathrm{U}$ - urban, $\mathrm{R}$ - rural, $\mathrm{H}$ - on highways and expressways as well as $\mathrm{T}-$ under all conditions

For both types of simulation tests, there is a clear similarity between national annual emission of pollutants from road shares in model traffic conditions. In all cases, the low sensitivity to road shares in model traffic conditions is national annual emission of pollutants under all traffic conditions. There is no clear sensitivity of the characteristics to the specific pollution.

\section{Conclusions}

Based on the simulations, the following conclusions can be drawn:

1. The sensitivity of the national annual emission of all pollutants was found to be relatively low to the share of road travelled by cars under model traffic conditions.

2. The national annual emission under all traffic conditions was least sensitive to the share of roads travelled by cars under model traffic conditions. This constitutes an important practical finding, since identifying the parameters that characterize vehicle movement belongs to the most difficult tasks.

3. The conclusions made on the basis of the study conducted apply to passenger cars. Based on the research carried out by the authors, it can be stated, that the sensitivity of the national annual pollutant emission to the share of road travelled by vehicles under model traffic conditions is lower for other cumulated vehicle categories than for passenger cars. However, reporting the results of the latter study exceeds the volume of the present work.

\section{Nomenclature}

CI compression ignition

$\mathrm{E}_{\mathrm{a}} \quad$ national annual emission

$\mathrm{H}$ highway

$\mathrm{N}$ number of vehicles per cumulated category

$\mathrm{p} \quad$ mileage covered by vehicles per cumulated category

$\mathrm{PC}$ passenger cars

PC-CI passenger cars - compression ignition (engine)

PC-SI passenger cars - spark ignition (engine)
R rural

SI spark ignition

$\mathrm{T}$ total (vehicles)

$\mathrm{u} \quad$ share of road travelled by vehicles per cumulated category under model traffic conditions

U urban

$\mathrm{v}$ average velocity of vehicles per cumulated category

\section{Bibliography}

[1] ARREGLE, J. et al. Procedure for engine transient cycle emissions testing in real time. Experimental Thermal and Fluid Science. 2006. Volume 30, no5. 485-496.

[2] BEBKIEWICZ, K., CHŁOPEK, Z., SZCZEPAŃSKI, K., ZIMAKOWSKA-LASKOWSKA, M. Results of air emission inventory from road transport in Poland in 2014. Proceedings of the Institute of Vehicles. 1(110)/2017. 77-88.

[3] BEBKIEWICZ, K., CHŁOPEK, Z., SZCZEPAŃSKI, K., ZIMAKOWSKA-LASKOWSKA, M. The influence of the properties of vehicles traffic on the total pollutant emission. Proceedings of the Institute of Vehicles. 1(110)/2017. 89102.

[4] BEBKIEWICZ, K., CHŁOPEK, Z., SZCZEPAŃSKI, K., ZIMAKOWSKA-LASKOWSKA, M. Issues of modeling the total pollutant emission from vehicles. Proceedings of the Institute of Vehicles. 1(110)/2017. 103-118.

[5] BUWAL (Bundesamt für Umwelt, Wald und Landschaft), INFRAS AG (Infrastruktur-, Umwelt- und Wirtschaftsberatung). Luftschadstoffemissionen des Strassenverkehrs 1950 2010. BUWAL-Bericht Nr. 255, 1995.
[6] CHŁOPEK Z., WAŚKIEWICZ J. The forecast of the pollutant emission from automotive internal combustion engines in Poland by 2030. VI International Congress of Internal Engines. 2015. Combustion Engines 2015.

[7] CHŁOPEK Z. Modelowanie procesów emisji spalin w warunkach eksploatacji trakcyjnej silników spalinowych. Prace Naukowe. Seria „Mechanika” z. 173. Oficyna Wydawnicza Politechniki Warszawskiej. Warszawa 1999.

[8] CHŁOPEK Z. Some remarks on engine testing in dynamic states. Combustion Engines 4/2010(143). 60-72.

[9] CHŁOPEK Z. Zasady modelowania zużycia paliwa i energii oraz emisji zanieczyszczeń związanych $\mathrm{z}$ użytkowaniem pojazdów drogowych. Technika Transportu Szynowego 12/15. 262-267.

[10] COPERT Training 5. COPERT 5 vs COPERT 4. European Environment Agency. 2016. http://emisia.com/sites/default/ files/COPERT_5_features.pdf. (2016-12-06).

[11] EMEP/EEA air pollutant emission inventory guidebook 2016. European Environment Agency. http://www.eea. europa.eu/publications/emep-eea-guidebook-2016. (201612-06). 
[12] GKATZOFLIAS D., KOURIDIS CH., NTZIACHRISTOS L., SAMARAS Z. COPERT 4 Computer programme to calculate emissons from road transport User manual (version 9.0). European Environment Agency. Emisia SA. 2012. (2016-12-06).
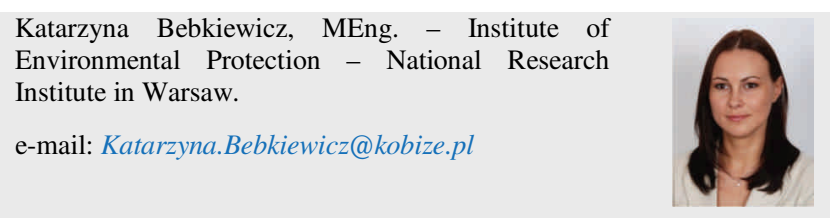

Prof. Zdzisław Chłopek, DSc., DEng. - Institute of Environmental Protection - National Research Institute in Warsaw.

e-mail: Zdzislaw.Chlopek@kobize.pl

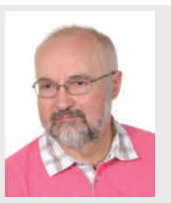

Grzegorz Stosio, Eng. - Faculty of Automotive and Construction Machinery Engineering in the Warsaw University of Technology.

e-mail: GrzegorzStosio@gmail.com
[13] INFRAS AG. Handbook emission factors for road transport 3.2. Quick reference. Version 3.2. Bern, 2014.

[14] 2006 IPCC Guidelines for National Greenhouse Gas Inventories. http://www.ipcc-nggip.iges.or.jp/public/2006gl/ vol2.html. (2016-12-06).

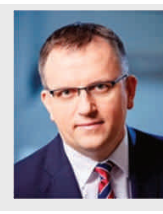

Magdalena Zimakowska-Laskowska, DSc., DEng. Institute of Environmental Protection - National Research Institute in Warsaw.

e-mail: Magdalena.Zimakowska-Laskowska@kobize.pl
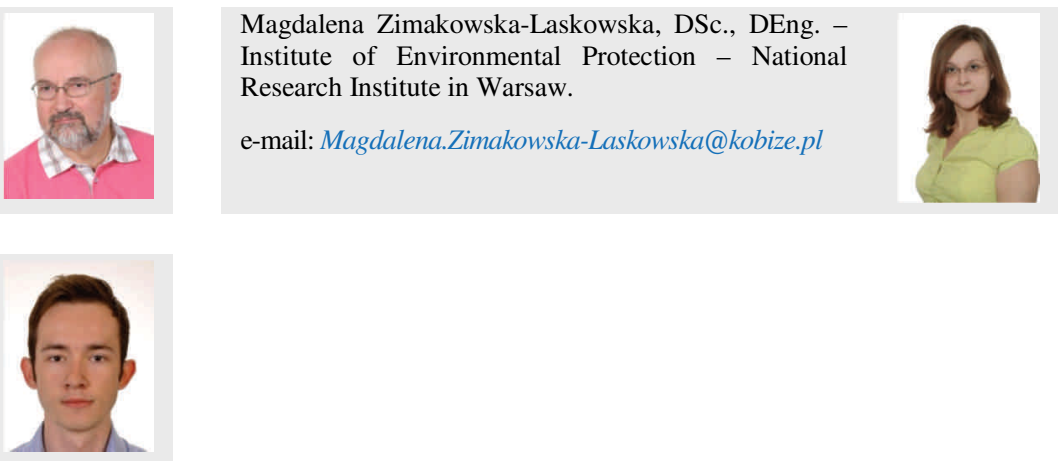